\title{
Molecular techniques employed to trace the Sicilian ovines
}

\author{
Viviana Giangreco, Ignazio Sammarco,Tiziana Lupo, Sergio Migliore \& Stefano Reale* \\ Istituto Zooprofilattico Sperimentale della Sicilia “A. Mirri”, Via G. Marinuzzi 3, 90129 Palermo, Italy \\ "Corresponding author, e-mail: stefano.reale@izssicilia.it
}

ABSTRACT

KEY WORDS
Genotyping strategies are aimed at defining the genetic profile of individuals through the identification of STRs sequences. The applied methodologies are able to ensure the traceability of the meat along the production chains and the control of the correct animal sampling on the farms. However, the discriminative capacity of alleles is studied through the establishment of the allelic frequency in the ovine population of the territory. This may depend on factors such as race, degree of inbreeding, and local selections. In the research of genetic identity in particular, it is exploited that the probability that two different individuals possess the same genetic pattern is equal to the frequency of that genotype in the population under examination and that the frequency of a genotype characterized by more loci is equal to the product of the frequencies of each single genotype (locus) observed. Therefore, we set the task of fixing and tabulating the data of the genetic profiles of the autochthonous breeds that can then be exploited for the traceability investigations of the animals, according to the application of specific algorithms. In practice, we aim to establish and create the starting point for the interpretation of all the genetic data obtained from the analysis of the Sicilian ovine population, whatever the application to do with it. The ultimate goal of this work is the elaboration of allelic panels typical of the sheep populations that represent the starting point for all genetic tests of forensic investigations. In fact, the discovery of particular alleles identify the tabulated frequency representing the genetic variability distribuited in the region. This has the effect of minimizing the identification errors that are spread in the animal population. We can state that from the analysis of allele frequencies developed by Genalex we can obtain expected heterozygosity data according to Hardy-Weinberg law and the obtained heterozygosity data typical for native breeds. All the allele frequencies were employed to create a database containing all the genotypes. These data were useful in the forensic field for the attribution of the kinships in the sheep.

Received 08.03.2018; accepted 29.04.2018; printed 30.06.2018; published online 05.07.2018

\section{INTRODUCTION}

Molecular genetics in forensic science finds application not only in the human field, but also in the veterinary, where such applications have allowed the development of multiple tools to ensure the protection of public health in the veterinary sector.

In this regard, there is a growing interest in the application, in the field of animal health, of the skills and methodologies developed in the field of individual genetic traceability for the determination 
of the genetic profile of an individual through the use of DNA polymorphisms.

Knowing the genetic profile of a single animal in relation to a certain polymorphism allows to:

- ensure complete traceability of the meat along the entire supply chain, from primary production to sales to consumers, with particular reference to products that have specific food qualities;

- ascertain the "pedigree" of heads of interest through genetic investigation of paternity and/or maternity;

- ascertain the identity of an animal found as a result of loss or in cases of abigeats; tackle suspected cases of poaching, acts of cruelty, and illegal imports of protected animals;

- identify the species and/or determine the sex;

- identify if an animal died in the barn or on the street;

- resolve cases of judicial or veterinary police.

Furthermore, the availability of effective, rapid, and cheap genetic identification systems for every sheep can be extremely useful in order to implement epidemiological control programs and surveillance of infectious diseases. The possibility to carry out genetic traceability analysis on biological samples collected for serological controls, in the context of surveillance programs, is undoubtedly a strong deterrent for the incorrect sampling procedures. This type of investigation requires a technique that combines sensitivity and high discriminating power, so as to allow researchers to use it even on minimum sample quantities and to trace and / or identify an individual in a univocal way and with a low margin of error.

\section{MATERIAL AND METHODS}

The genetic analysis will be carried out on samples of peripheral blood with EDTA anticoagulant, taken from the sheep, and sent to the reference laboratories for the territories under the jurisdiction of the Experimental Zooprophylactic Institute of Palermo. Arbitrarily, 480 samples were considered as representative of the breed variety of the Sicilian territory for the control of genetic susceptibility to scrapie with molecular analysis. The data that are generated, for their interpretation, require a mathematical matrix that takes into account the allelic distribution throughout the population, so that each allele found, is then identified with a frequency index. Genomic DNA extracted from blood with the Genelute Blood Genomic DNA Kit from Sigma allows the identification of every animal and therefore can be useful in document traceability in animal products of sheep origin. A PCR was used for the amplification process, on which an end point study was performed to assess the presence of the sequences of interest, according to an AmpliTaq Gold $^{\mathrm{TM}} 360$ DNA Polymerase Kit which provides a genetic system based on the simultaneous amplification of the STR markers of interest by PCR, and also allows sequence analysis for capillary electrophoresis. The Kit contains:

Primer mix,

PCR Buffer,

dNTP mix,

DNA control,

Taq Gold DNA Polymerase.

The Mix primer is the mixture of the primers forward and reverse, for each locus to be analyzed. For each pair one of them is marked with a fluorescent dye of the type: FAM, HEX, ROX. Specific primers for different loci that fall in overlapping dimensional ranges are however diversifiable thanks to different fluorochrome markings. For amplification, 11 STR dinucleotide markers were recommended, for identification purposes in the sheep, by ISAG (International Society of Animal Genetics) and listed below in Table 1 together with the fluorescent molecule with which they are labeled after PCR, the resulting color, the number of alleles found in the Sicilian population, and the interval of length of alleles for each locus.

The ISAG markers, validated at European level for their information, are used by independent laboratories all over Europe as a basic panel of standard markers for the analysis of sheep genotypes. Within each range, for a single locus, it is possible to find one or two peaks between those coded in Table 2 that collects all the allelic groups. For each sample analyzed, $2 \mu \mathrm{l}$ of DNA at the concentration of $20 \mathrm{ng} / \mathrm{ml}$, prepared in the previous phases, was amplified in a final volume of $25 \mu \mathrm{l}$ of the reaction mixture formed by 2 mixes. The mix 1 and 2 were composed as follow: $12.5 \mu \mathrm{l}$ of Master mix, $2.5 \mu \mathrm{l}$ primer mix, $10 \mu \mathrm{l}$ water. The amplification program provides $95^{\circ} \mathrm{C}$ for 5 minutes, $95^{\circ} \mathrm{C}$ for 30 seconds, 
$63{ }^{\circ} \mathrm{C} 90$ seconds, $72{ }^{\circ} \mathrm{C} 30$ seconds, $60{ }^{\circ} \mathrm{C} 30 \mathrm{~min}-$ utes, $4{ }^{\circ} \mathrm{C}$ kept in a final volume of $30 \mu \mathrm{l}$. The same amplification program is used for mix 2, with the only difference being the annealing temperature at $56{ }^{\circ} \mathrm{C}$ for 90 second. The amplifications were conducted on the thermal cycler "GeneAmp PCR system 9700 (Applied-Biosystems)". After the PCR, the product should be diluted 1:10 (25 $\mu$ l of amplified $+225 \mu$ l of deionized water). A volume of $2 \mu 1$ of PCR products were added to the formammide and the internal size standard (Rox). This sample mixtures were loaded in the sequencer in opportune order: (see Nei et al. (1983), Guo \& Thompson (1992), MacHugh et al. (1998), Blott et al. (1999), Cornuet et al. (1999), Roques et al. (1999), Ciampolini et al. (2000), Pritchard et al. (2000), Bjørnstad \& Røed (2001), Hansen et al. (2001), Caballero \& Toro (2002), Maudet et al. (2002), Dieringer \& Schlotterer (2002), Korstanje et al. (2003), Mburu et al. (2003), Queney et al. (2004), Rosenberg (2004), Chantry-Darmon et al. (2005), Excoffier et al. (2005), Gutirrez et al. (2005), Barcaccia \& Falcinelli (2006), Whitlock et al. (2008), ISAG/FAO Standing Committee (2009).

\begin{tabular}{|c|c|c|c|l|l|}
\hline PROG & LOCI & DYE & SIZE & $\begin{array}{l}\text { SEQUENCE } \\
\text { FORWARD } \\
\text { (Fwd) }\end{array}$ & $\begin{array}{l}\text { SEQUENCE } \\
\text { REVERSE (Rev) }\end{array}$ \\
\hline 1 & $\begin{array}{l}\text { OV OarFCB011- } \\
\text { FORW }\end{array}$ & FAM & $120-150$ & $\begin{array}{l}\text { GCAAGCAGGTT } \\
\text { CTTACCACTA } \\
\text { GCACC }\end{array}$ & $\begin{array}{l}\text { GGCCTGAACTC } \\
\text { ACAAGTGATA } \\
\text { TATCTATCAC }\end{array}$ \\
\hline 2 & INRA0063 & FAM & $160-210$ & $\begin{array}{l}\text { GACCACAAAGG } \\
\text { GATTTGACAA } \\
\text { GC }\end{array}$ & $\begin{array}{l}\text { AAACCACAGAA } \\
\text { ATGCTTGAAG }\end{array}$ \\
\hline 3 & HSC & FAM & $260-300$ & $\begin{array}{l}\text { CTGCCAATGCA } \\
\text { GAGACACAAG } \\
\text { A }\end{array}$ & $\begin{array}{l}\text { GTCTGTCTCCT } \\
\text { GTCT TGTCATC }\end{array}$ \\
\hline 4 & OarCP0049 & HEX & $80-140$ & $\begin{array}{l}\text { CAGACACGGCT } \\
\text { TAGCAACTAAA } \\
\text { CGC }\end{array}$ & $\begin{array}{l}\text { GTGGGGATGAA } \\
\text { TAATCCTCAT } \\
\text { AAGG }\end{array}$ \\
\hline 5 & OarFCB0304 & HEX & $150-190$ & $\begin{array}{l}\text { CCCTAGGAGCT } \\
\text { TTCAATAAAGA } \\
\text { ATCGG }\end{array}$ & $\begin{array}{l}\text { CGCTGCTGTCA } \\
\text { ACTGGTCAGG } \\
\text { G }\end{array}$ \\
\hline 6 & CSRD0247 & HEX & $210-260$ & $\begin{array}{l}\text { GGACTTGCCAG } \\
\text { AACTCTGCAAT }\end{array}$ & $\begin{array}{l}\text { CACTGTGGTT } \\
\text { GTATAGTCAG } \\
\text { G }\end{array}$ \\
\hline
\end{tabular}

Table 1. Sequences of ISAG loci and primers for the MIX1 (panel locus multiplex1).

\begin{tabular}{|c|c|c|c|l|l|}
\hline PROG & LOCI & DYE & SIZE & $\begin{array}{l}\text { SEQUENCES } \\
\text { FORWARD } \\
\text { (Fwd) }\end{array}$ & $\begin{array}{l}\text { SEQUENCES } \\
\text { REVERSE (Rev) }\end{array}$ \\
\hline 1 & OarFCB0020 & FAM & $90-120$ & $\begin{array}{l}\text { GGAAAACCCCC } \\
\text { ATATATACCTA } \\
\text { TAC }\end{array}$ & $\begin{array}{l}\text { AAATGTGTTA } \\
\text { AGATTCCATAC } \\
\text { ATGTG }\end{array}$ \\
\hline 2 & D5S2 & FAM & $180-210$ & $\begin{array}{l}\text { TACTCGTAGGG } \\
\text { CAGGCTGCCTG }\end{array}$ & $\begin{array}{l}\text { GAGACCTCAGG } \\
\text { GTGGTGATCA } \\
\text { G }\end{array}$ \\
\hline 3 & SPS0113 & FAM & $220-260$ & $\begin{array}{l}\text { AAAGTGACACA } \\
\text { ACAGCTTCTCC } \\
\text { AG }\end{array}$ & $\begin{array}{l}\text { AACGAGTGTCC } \\
\text { TAGTTGGCTG } \\
\text { TG }\end{array}$ \\
\hline 4 & INRA0005 & HEX & $120-160$ & $\begin{array}{l}\text { TTCAGGCATAC } \\
\text { CCTACACCACA } \\
\text { TG }\end{array}$ & $\begin{array}{l}\text { AAATATTAGCC } \\
\text { AACAAAACT } \\
\text { GGG }\end{array}$ \\
\hline
\end{tabular}




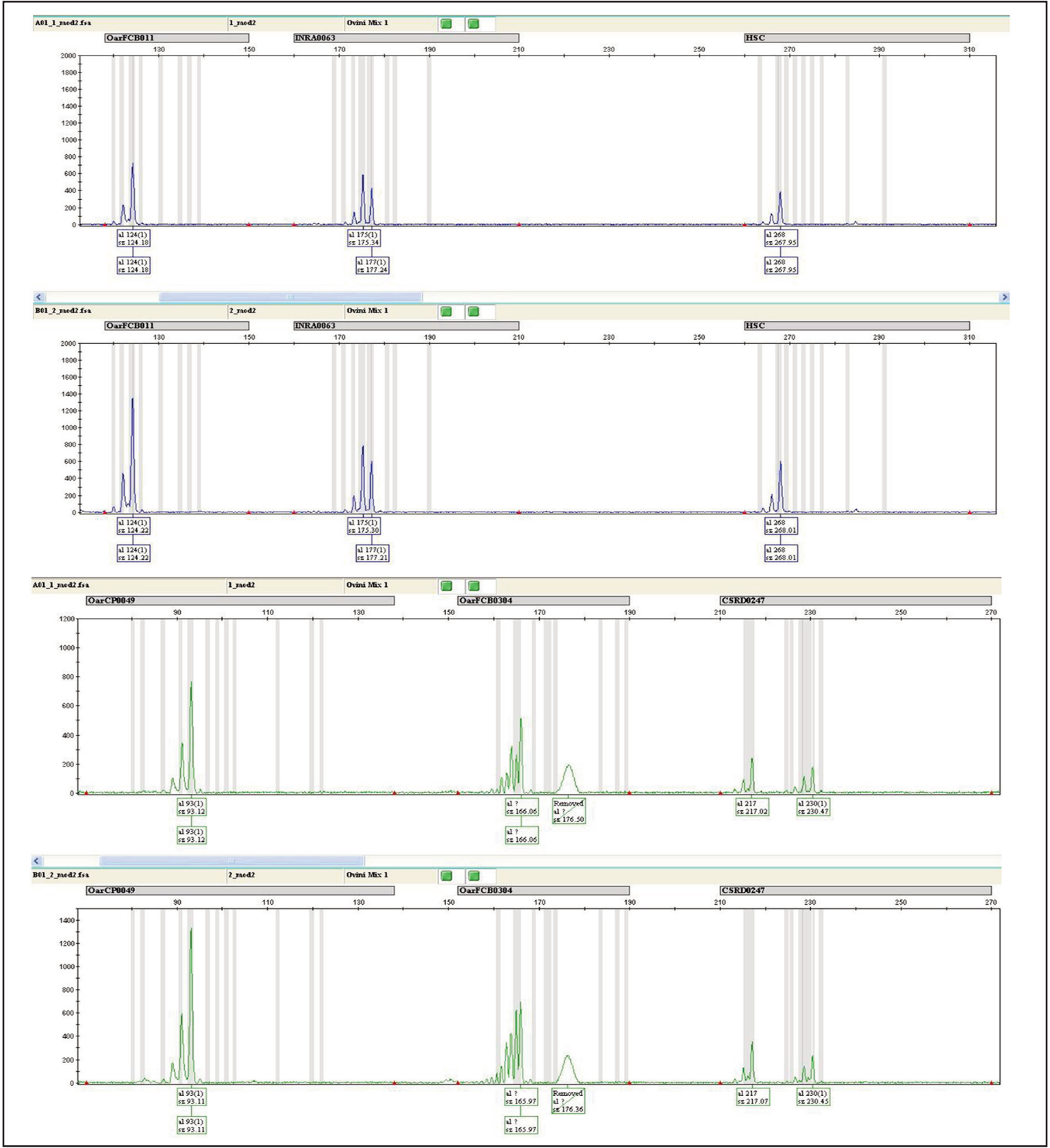

Figure 1. Electropherograms obtained during the genetic tests on Sicilian ovines.

\section{RESULTS AND CONCLUSIONS}

In figures 1, 2 some representative examples of electropherograms obtained during the genetic tests are shown.

These panels were obtained for all the samples examined and were used to collect polymorphic patterns based on STR. The colors indicate the various markers (FAM and HEX). All these data were tabulated for subsequent statistical processing.

At the moment the following objectives have been achieved:

- Optimization of the analytical method.

- Standardization of the use of selected markers. 
These steps led to the preliminary analysis of allele frequencies and the database for the Sicilian sheep is currently being constructed by loading all the genotypes for each locus in the GeneAlex database in order to obtain the most common alleles. Expected heterozygosity data according to HardyWeinberg law and obtained heterozygosity. All this could be characterized by the autochthonous breeds and serves to construct the matrix of genotypes in terms of allele frequencies, used in forensic genetics for the attribution of possible kinships between the sheep.

\section{REFERENCES}

Barcaccia G. \& Falcinelli M., 2006. Marcatori Molecolari RFLP e PCR- derivati. Genetica e Gnomica, 3: 832-834.

Bjørnstad G. \& Røed K.H., 2001. Breed demarcation and potential for breed allocation of horses assessed by microsatellite markers. Animal Genetics, 32: 59-65. DOI: 10.1046/j.1365-2052.2001.00705.x

Blott S.C., Williams J.L. \& Haley C.S., 1999. Discriminating among cattle breeds using genetic markers. Heredity, 82: 613-619. DOI: 10.1046/j.1365-2540. 1999.00521.x

Caballero A. \& Toro M., 2002. Analysis of genetic diversity for the management of conserved subdivided populations. Conservation Genetics, 3: 289-299. DOI: 10.1023/A:1019956205473

Chantry-Darmon C., Urien C., Hayes H., Bertaud M., Chadi-Taourit S., Chardon P., Vaiman D., RogelGaillard C., 2005. Construction of a cytogenetically anchored microsatellite map in rabbit. Mammalian Genome, 16: 442-459.

Ciampolini R., Leveziel H., Mazzanti E., Grohs C. \& Cianci D., 2000. Genomic identification of the breed of an individual or its tissue. Meat Science, 54: 3540. DOI: 10.1016/S0309-1740(99)00061-3

Cornuet J.M., Piry S., Luikart G., Estoup A. \& Solignac M., 1999. New methods employing multilocus genotypes to select or exclude populations as origins of individuals. Genetics, 153: 1989-2000.

Dieringer D. \& Schlotterer C., 2002. Microsatellite analyser (MSA): a platform independent analysis tool for large microsatellite datasets. Molecular Ecology, Notes 3: 167-169. DOI: 10.1046/j.1471-8286.2003. 00351.x

Excoffier L., Laval G. \& Schneider S., 2005. Arlequin (version 3.0): An integrated software package for population genetics data analysis. Evolutionary Bioinformatics Online, 1: 47-50.
Guo S.W. \& Thompson E.A., 1992. Performing the exact test of Hardy-Weinberg proportion for multiple alleles. Biometrics, 48: 361-372. DOI: 10.2307/2532296

Gutirrez J., Royo L., Alvarez I. \& Goyache F., 2005. Molkin v2.0: A computer Program for Genetic Analysis of popolations Using Molecular Coancestry Information. Journal of Heredity, 96: 718-721. DOI: 10. 1093/jhered/esi118

Hansen M.M., Kenchington E. \& Nielsen E.E., 2001. Assigning individual fish to populations using microsatellite DNA markers: Methods and applications. Fish and Fisheries, 2: 93-112. DOI: 10.1046/j.14672960. 2001.00043.x

Korstanje R., Gillissen G.F., Versteeg S.A., Van Oost B.A., Bosma A.A., Rogel-Gaillard C., Van Zutphen L.F.M. \& Van Lith H.A., 2003. Mapping of rabbit microsatellite markers using chromosome-specific libraries. Journal of Heredity, 94: 161-169. DOI: 10.1093/jhered/esg016

ISAG/FAO Standing Committee, 2009. Secondary Guidelines for Development of National Animal Genetic Resources Management Plans. Measurement of Domestic Animal Diversity (MoDAD): Recommended Microsatellite Markers. Recommendations of joint ISAG/FAO Standing Committee. http://dad.fao.org/ Accessed January 26, 2017.

Maudet C., Luikart G. \& Taberlet P., 2002. Genetic diversity and assignment tests among seven French cattle breeds based on microsatellite DNA analysis. Journal of Animal Science, 80: 942-950. DOI: 10. 2527/2002.804942x

Mburu D.N., Ochieng J.W., Kuria S.G., Jianlin H., Kaufmann B., Rege J.E. \& Hanotte O., 2003. Genetic diversity and relationships of indigenous Kenyan camel (Camelus dromedarius) populations: implications for their classification. Animal Genetics, 34: 26-32. DOI: 10.1046/j.1365-2052.2003.00937.x

MacHugh D.E., Loftus R.T., Cunningham P. \& Bradley D.G., 1998. Genetic structure of seven European cattle breeds assessed using 20 microsatellite markers. Animal Genetics, 29: 333-340. DOI: 10.1046/j.13652052.1998.295330.x

Nei M., Tajima F. \& Tateno Y., 1983. Accuracy of estimated phylogenetic trees for molecular data. Journal of Molecular Evolution, 19: 153-170.

Pritchard J.K., Stephens M. \& Donnelly P., 2000. Inference of population structure using multilocus genotype data. Genetics, 155: 945-959.

Queney G., Vachot A.M., Brun J.M., Dennebouy N., Mulsant P. \& Monnerot M., 2004. Different levels of Human intervention in domestic rabbits: effects on genetic diversity. The Journal of Heredity, 93: 205209. DOI: $10.1093 /$ jhered/93.3.205

Roques S., Duchesne P. \& Bernatchez L., 1999. Potential of microsatellites for individual assignment: the 
North Atlantic redfish (genus Sebastes) species complex as a case study. Molecular Ecology, 8: 17031717. DOI: 10.1046/j.1365-294x.1999.00759.x

Rosenberg N.A., 2004. Distruct: a program for the graphical display of population structure. Molecular Ecology Notes, 4: 137-138.
Whitlock R., Hipperson H., Mannarelli M., Butlin R.K. $\&$ Burke T., 2008. An objective, rapid and reproducible method for scoring AFLP peak-height data that minimizes genotyping error. Molecular Ecology Resources, 8: 725-735. DOI: 10.1111/j.1755-0998. 2007.02073.x 